CHANDLER, Nick - HEIDRICH Balázs

\title{
HAJSZA KÖZBEN
}

\section{EGY MAGYAR FELSŐOKTATÁSI INTÉZMÉNY PIAC- ORIENTÁCIÓJÁNAK KULTÚRAALAPÚ ELEMZÉSI KÍSÉRLETE}

\begin{abstract}
A tanulmány célja egy felsôoktatási intézmény példáján keresztül azonosítani és megvizsgálni a szubkultúrákat, illetve azok hatását a piacorientált múködésre. A szerzók a szubkultúrák azonosítását követően bemutatják a szubkultúrák természetét, különös tekintettel a homogenitással és heterogenitással való viszonyukra. Tanulmányuk a piacorientációt a tisztán stratégiai szempont helyett a piacorientációt a szervezeti kultúra kontextusában vizsgálja (pl. az összes alkalmazott szintjén). A kérdés azonban, amire ez a tanulmány is keresi a választ, továbbra is fennáll: a felsôoktatási intézmény lassan változó szervezeti kultúrája és szubkultúrái mennyire támogatják az olyannyira szükséges piacorientáltságot?
\end{abstract}

Kulcsszavak: felsốoktatás, szubkultúrák, kultúratípusok, piacorientáció

„Én az idốt nem sajnálom, csak élni szeretnék...” (Prognózis: Hajsza közben)

2012 szeptemberében a magyar felsóoktatási intézmények múködését nagymértékben befolyásolták a kormány arra irányuló tervei, hogy csökkentik a felsốoktatási intézmények és a hallgatók pénzügyi támogatását, különös tekintettel a jogi és üzleti ismeretekhez kapcsolódó képzésekre. ${ }^{1}$ Azon hallgatók, akik bölcsészettudományi, múvészeti és gazdasági ismeretekkel összefüggó képzésekre szerettek volna beiratkozni, 2012-tól gyakorlatilag semmilyen támogatást nem kapnak, míg a természettudományi, mérnöki, informatikai és orvostanhallgatóknál kismértékben növelik az államilag támogatott helyek számát (Temesi, 2012). A helyzet azóta némileg enyhült, noha az állami támogatás elnyeréséhez szükséges nagyon magasan megállapított pontszámok, képzésterületenként, gyakorlatilag egy-egy országos elérésú (ti. budapesti) intézmény számára jelentenek bármi változást a kiinduló állapot kihívásaihoz képest.

Egy ilyen bizonytalan jövôkép esetén a szervezeti kulturális megközelítés lehet az egyik, amivel az intézmények reakciói megjósolhatók, megérthetók, és akár kezelhetók is (Tierney, 1988), továbbá a kultúra lehet az az eszköz vagy stabil alap, amire a siker építhető. A szervezet homogenitásának vagy fragmentáltságának mértéke befolyásolhatja annak teljesítményét, de leg- alábbis jelzi azon alkalmazottak számát és csoportosulásait, akik képesek döntô szerepet vállalni, amikor a szervezetnek egy új irányt kell vennie (Martin, 1992). Ezenfelül a változással szembeni potenciális ellenállás módszereit is segíthet meghatározni. Felismervén az ilyen szubkultúrák kialakulásának alapjait, új munkaerôkiválasztási stratégiák jöhetnek létre a jövőre nézve, amikor a szervezet nem csupán olya n embereket keres, akik képesek beilleszkedni a kultúrába és a szubkultúrákba, hanem egyben nyitottak a piacorientáció irányába is.

Ezenfelül a homogenitás mértéke, továbbá a szubkultúrák létrejöttének és típusainak alapjai mind-mind kulcsfontosságú tényezốként szolgálnak a változásmenedzsment folyamatának tervezéséhez és lebonyolításához, melynek során a szervezet arra törekedhet, hogy a szubkultúrákat a domináns szervezeti kultúra kívánt típusához és orientációjához igazítsa.

Jelen tanulmány célja egy felsőoktatási intézmény példáján keresztül azonosítani és megvizsgálni a szubkultúrákat, illetve azok hatását a piacorientált múködésre. Hazánkban is számos értékes tanulmány készült már egyetemek, foóiskolák külsô, stratégiai helyzetének azonosítására (Barakonyi, 2010; Berács, 2001; NagyBerács, 2013), ezek fókusza azonban természetesen máshová esik. 
A szubkultúrák azonosítását követôen a feladat a szubkultúrák természetének felmérése, különös tekintettel a homogenitással és heterogenitással való viszonyukra. Cameron és Quinn (1999), a vizsgálatban használt módszer (az OCAI) megalkotói, a kulturális egybevágóságot tekintik a szervezeti kultúra homogenitás egyik aspektusának, mely kevesebb belső konfliktust és ellentétet eredményez.

A jelen tanulmányban alkalmazott módszertan nem csupán az oktatási szektorban múködố intézményekre érvényes, hanem egyéb, nagyméretú, komplex szervezetekre is, ahol a szubkultúrák és azon képességek azonosítására van szükség, hogy mennyire képesek követni a vállalat által meghatározott célokat és múködési orientációt, illetve ahol lényeges azon szubkultúrák célokhoz való igazítása, amelyek nem a vállalat által felvázolt stratégiával összhangban múködnek. A tanulmányunk szervezeténél is megjelent az összeolvadást követően a szubkultúrák piacorientációjának potenciális hatásvizsgálata. Ez az alábbi fontos kérdéseket vetette fel:

- idegen kultúrákhoz való alkalmazkodás,

- a kultúrák egyesülést követô illeszkedése vagy ütközése,

- a szubkulturális kontextus szervezeti orientációra és hatékonyságra gyakorolt hatása.

\section{A vizsgált szervezet bemutatása}

A vizsgálatban részt vevố szervezet három fốiskola egyesülésével jött létre 2000-ben. A három foóiskola közül kettốt 1857-ben alapították, míg a harmadikat 1957ben. Az egyes fóiskolák, melyek az egyesülést követôen az új szervezet karaiként jelennek meg, külön-külön tudományokra összpontosítanak az alábbiak szerint:

1. külkereskedelem és nemzetközi üzlet,

2. pénzügy és számvitel,

3. turizmus és vendéglátás.

Az intézmény a felsófokú szakképzéstôl kezdve az alapfokú képzéseken keresztül, a mester-, valamint a külföldi társintézményekkel együtt folytatott doktori képzésig minden képzési szinten megjelenik.

Az összeolvadás eredményeképpen a fơiskola Magyarország ötödik legnagyobb felsőoktatási intézményévé vált, mely ma körülbelül 17.000 hallgató képzését biztosítja. A szervezeti kultúra szempontjából a tény, hogy a fóiskolák a saját kampuszaikban maradtak ahelyett, hogy fizikailag is egybeolvadtak volna, jelentôs akadályt jelentett az integrációval szemben. A szervezeti struktúra mátrixformájának köszönhetôen a karok egyes tanszékei mind a dékánnak, mind az egységük vezetójének elszámolással tartoznak. Ez fenntartja és elősegíti a karok közötti integrációt és homogenitást. A tanszékeket intézetek fogják össze szakmailag, az intézet vezetôje mindhárom karon felelôs a szaktanszékéért.

\section{A karok kulturális öröksége}

Noha a kutatásnak tudatosan nem volt célja, hogy az egyes karok szervezeti kultúráját azonosítsa szubkultúraként, mégis érdemes a 2000-es összeolvadás elôtti, egyes fốiskolákra vonatkozó kulturális elemeket rögzíteni, a késóbbi eredmények könnyebb kontextuális értelmezése érdekében.

\section{„A" Kar}

A külkereskedelmi képzés egyik hazai fellegvára, oktatói gárdájában hagyományosan sok a volt külszolgálatot teljesítő (többek között nagykövet) és külföldi képviseleteken évtizedeket dolgozó munkatárs. Így hallgatóinál és oktatóinál is egyértelmú elvárás a többnyelvúség. Ez tükrözódik az oktatásban is, ahol már a kilencvenes évektől zajlanak például angol és francia, külföldi társintézménnyel vagy önállóan folytatott, diplomát adó képzések. A köztudatban az intézmény leginkább kiváló nyelvi képzése miatt volt méltán népszerú. A kar képzéseinek fókuszában a nemzetközi gazdálkodási, nemzetközi tanulmányok, valamint a kereskedelem és marketing, valamint az üzleti kommunikációs képzések állnak.

\section{„B" Kar}

A turizmus és vendéglátás legismertebb hazai képzóhelye. Széles körú nemzetközi kapcsolatokkal rendelkezik minden kontinensen, ami a hallgatók felé világszerte széles körú szakmai gyakorlati helyeket biztosít. A szakmai területból adódóan nagyon erôs a gyakorlati képzés jelentôsége, valamint a nyelvi képzés színvonala, minősége. Hazai viszonylatban nagy a külföldi hallgatók részaránya. Német és angol nyelven is folytat diplomát adó képzéseket. Képzési kínálatában a turizmus és vendéglátás, a kereskedelem és marketing, valamint az üzleti pedagógiai képzések alkotják a legnagyobb hányadot. A foóiskolai képzésen túlmenően jelentốs a felső́fokú szakképzés aránya, elsôsorban az üzletiasszisztens-képzés.

$$
\text { „C” Kar }
$$

A pénzügyi és számviteli szakma legismertebb magyar képzóhelye, valaha a Pénzügyminisztérium fennhatósága alá tartozó oktatási intézmény. Gyakorlatorientáltságát oktatóinak napi szintú vállalati tapasztalatai és a tudományos munkán túl, a szakmai végzettségek (pl . könyvvizsgálók) biztosítják. A pénzügy és a számvitel területén a végzett szakemberek meghatározóak 
a szakterületen. A magyar könyvvizsgálók jelentős hányada az intézményben szerzett oklevelet. Az említett területeken jelentôs továbbképzési szereplóként is ismert a piacon. Felsôoktatási képzési palettája meglehetôsen széles, a pénzügy és számvitel többszintú képzései mellett gazdálkodási és menedzsment, gazdasági informatikus és emberi erôforrás szakokon is jelentős számú hallgatóval bír.

\section{Piacorientáció a magyar felsôoktatásban}

Mielốtt továbblépnénk a magyarországi felsőoktatási intézmény konkrét esetére, elóbb a piacorientáció felsőoktatásban betöltött szerepét szükséges tisztázni. Kasper (2005) szerint kapcsolat van a szervezet stratégiája, kultúrája és piacorientációja között. A vélemények azonban különböznek a piacorientációhoz kapcsolódó szervezeti értékekról. Kasper (2005) a piaci kultúra típusait a következóképp jellemezte:

- domináns jellemzók, mint a versenyképesség és a célorientáltság,

- határozott és eredményorientált vezetôi stílus,

- a szervezethez kötés a célorientáción, a múködésen és a versenyen keresztül valósul meg,

- versenyelőnyön és piacvezetésen alapuló stratégia.

Narver és Slater (1990) a piacorientációt a fogyasztók, a versenytársak és a funkciók közötti koordinálásként értelmezi. Felsőoktatási szempontból, ha a hallgatót tekintjük fogyasztónak, abban az esetben a hallgató elégedettsége kerül a piacorientált felsőoktatási intézmény fókuszába.

Kohli és Jaworski (1990) a piacorientációt az intelligencia létrehozása és terjesztéseként, valamint alkalmazkodóképességként határozza meg. Ez utóbbi úgy túnik, egyre inkább valóban követelmény a felsôoktatási környezetben is.

Slater (2001) szerint a piacorientáció a vásárlók igényei körül összpontosul, a szervezet célja pedig ezen igények kielégítése. A tisztán stratégiai szempont helyett tanulmányunk a piacorientációt a szervezeti kultúra kontextusában vizsgálja (pl. az összes alkalmazott szintjén).

Hofstede (1991) dimenzióit használva Kasper (2005) arra a konklúzióra jutott, hogy a piaci kultúrák inkább pragmatikusak, mint normatívak, így a vásárlói igények prioritást élveznek az eljárások felett, illetve erős külső fókuszt jelentenek (a versenyben). Day (1999: p. 6.), valamint Cameron és Quinn (1999) megerósítik, hogy a piacorientáció részeként szükség van a külsóleg fókuszált kultúrára (2005). Úgy találták, hogy a piacorientált szervezet kultúrájának eredmény- és alkalmazott orientált- nak, valamint szakmai alapúnak (ti. professzionálisnak) kell lennie. Hurley és Hult (1998: p. 45.) erős kapcsolatot talált a piacorientáció és az innováció között: „, $A$ piac- és oktatásorientált kultúra, egyéb más tényezóvel együtt elósegíti az új ötletekre és innovációkra való fogékonyságot a szervezet kultúrájának részeként."

A piacorientáció bizonyos mértékben eltérô lehet a szervezetek között. Kasper (2005: p. 6.) szerint: , a valóban piacorientált szervezettól kezdve az egyáltalán nem piacorientált szervezetekig mindenféle létezik." Ugyanitt a piacorientációt a következók szerint definiálja: „,annak mértéke, hogy egy szervezet elképzeléseit és cselekedeteit mennyire irányítja magának a szervezetnek és a fogyasztóinak a piaci viselkedése (legyen az belsó vagy külsó)" (Kasper, 2005: p. 6.). Habár a piacorientáció nem az egyetlen tényező, mellyel versenyelónyre lehet szert tenni, Day (1999) szerint a következók segítségével is információt lehet szerezni a piacot érintô trendekról:

- nyílt információáramlást lehetővé tevő légkör létrehozása,

- a versenytársak cselekedeteinek elemzése,

- a frontvonalban dolgozó alkalmazottak véleményének megismerése,

- a rejtett igények felkutatása,

- a piac aktív figyelése és

- a folyamatos kísérletezés támogatása.

Nem minden szervezet képes olyan versenyképes, fogyasztói érdekeket figyelembe vevő megközelítést kifejleszteni, mely ne tenne kárt a szervezet hagyományaiban (Chandler, 2011).

A felsőoktatási intézmények egyensúlyra törekszenek a külsố igények, valamint az alkalmazottak által vallott értékek és igényeik között. Az egyetemek és föiskolák stratégiájában és struktúrájában történố változásokat gyakran befolyásolják különféle külsố és belsô tényezók. A szervezetek gyakran reagálnak összeolvadással az ilyen külső befolyásoló tényezókre, mely az újraszervezésnek az egyik legradikálisabb formája (Chafee - Tierney, 1988). Hemsley-Brown - Oplatka (2010) szerint a felsóoktatási intézmények marketingje a kapcsolatmarketingen alapul. A hallgatót fogyasztónak, a szervezeti kultúrát pedig hallgatóorientáltnak szükséges tekinteni. Amennyiben a piacorientációt (MO) koncepcióként fogjuk fel, a felsőoktatási intézménynek a következô dimenziókat is figyelembe kell vennie: fogyasztóorientáció, versenyorientáció és funkciók közötti orientáció (Narver - Slater, 1994; Oplatka - Hemsley-Brown, 2007).

A magyarországi felsőoktatás olyan változásokon megy keresztül, melyek hatására számos felsőoktatási intézmény kénytelen nagyobb hangsúlyt fektetni a 
piacorientációra. Day (1999: p. 9.) azt állítja, hogy a piaci instabilitás légköre és a fokozódó verseny számos szervezetnél intenzívebb piacorientációt eredményezett. A változást befolyásoló tényezốk az állami és a privát kézben lévố szervezetek esetén is a következók lehetnek: globalizáció, gazdasági racionalizmus és információtechnológiai fejlesztés (Burke - MacKenzie, 2002; Weber - Weber, 2001).

Az esettanulmányban szereplő felsôoktatási intézmény korábban talán még sohasem volt olyan helyzetben, ahol a piacorientáció ennyire komolyan elótérbe került volna. Az intézmény erôssége, hogy az egyik leginkább gyakorlatorientált üzleti iskola lévén a magyar piacon jó hírnévvel rendelkezik. Stratégiai szinten az oktatás gyakorlatorientáltságának, a vállalati együttmúködések és projektek erôsítésének, valamint a hallgatók részére nyújtandó, korábban nem létezố vállalati ösztöndíjak növelésének feladatait az intézmény vezetése már teljesítette első lépcső́ként. A kérdés azonban, amire ez a tanulmány is keresi a választ, továbbra is fennáll: a felsôoktatási intézmény lassan változó szervezeti kultúrája és szubkultúrái mennyire támogatják az olyannyira szükséges piacorientáltságot?

\section{A felsöoktatás kulturális komplexitása}

A homogénnek feltételezett szervezeti kultúra koncepcióját egységes vagy integrált megközelítésnek tekintjük, amely így lehetôvé teszi a szervezeti kultúra Handy (1993) tanulmányában használt négy kultúratípusba történó besorolását: feladat-, hatalom-, ember- és szereporientált kultúrák. Hofstede (1980) szerint a szervezetek szerep-, teljesítmény-, hatalom- és támogatókultúrákkal rendelkeznek. De minél nagyobb és komplexebb egy szervezet, annál kisebb az esélye a monolitikus kultúra kialakulásának, tehát annál kisebb az esélye, hogy a szervezetben dolgozó összes személy számára ugyanazok a dolgok jelentsék az értékeket. Kuh és Whitt (1988: p. 27.) is ezt hangsúlyozza a felsôoktatási környezet kapcsán: „,a »kicsi, homogén társadalom " analógia... mindenképp torzul, ha azt mai felsőoktatási intézményekre alkalmazzuk." Ezen túlmenóen Bowen és Schuster (1986) arra jutott, hogy a különböző tudományos diszciplínák képviselői különböző értékeket, attitüdöket és személyes jellemzóket mutatnak. Ehhez hasonlóan Cameron és Quinn (1999) a szervezeti kultúrát vizsgáló rendszer (OCAI) fejlesztése során a versengő értékek modelljére alapozva megtartotta azt a feltételezést, hogy adott időben egy szervezeten belül több kultúra is létezhet.

Ez az egyidejû́ kulturális heterogenitás látszólag lehetôvé teszi a különbözó funkciók és szakmák, helyszínek és más gyưjitó ismérvek kombinációját, melyek a felsőoktatásban is megtalálhatók; mégis felmerül a kérdés, hogy ezek a kultúratípusok létezhetnek-e egymás mellett egy kultúrán belül, vagy csak indikátorai a szervezeti kultúra fragmentációjának. A szubkultúrák sokkal nagyobb eséllyel alakulnak ki bürokratikus, nagyobb vagy komplexebb szervezeteknél, mivel ezek a szervezetek sokkal nagyobb valószínúséggel alkalmaznak számos különböző funkciót és technológiát (Trice - Beyer, 1993).

Becher (1987: p. 292.) felveti annak a lehetôségét, hogy további alcsoportok alakulnak ki a karokon belül, a szakokhoz igazodva, és hogy ezek között ténylegesen átfedések létezhetnek. Tierney (1988) azt állította, hogy egy egyetemen vagy fớiskolán számos szubkultúra létezhet, aminek alapjául a következók szolgálhatnak: vezetôii, tudományterület-alapú oktatói csoportok, szakmai személyzet, oktatói és hallgatói társadalmi csoportok, kollegiális csoportok (hasonló érdeklődés vagy fizikai közelség alapján) és hely (tudományágak szerint elrendezett irodák).

Így jogosan tehetô fel a kérdés, hogy a felsôoktatási intézetek szervezeti kultúrája homogén vagy heterogén-e? Schein (1988) felveti annak lehetóségét, hogy a szervezet tagjai rendelkezhetnek a közösen vallott és az eltérô értékek kombinációjával is, a központi és periférikus értékekben egyaránt. Központi értékek azok, amelyek lényeges szerepet játszanak egy szervezet múködésében, a tagoknak alkalmazkodniuk kell az ezekból az értékekból származtatott viselkedési normákhoz, és jellemzóen kizárják óket a szervezetből, ha ennek nem tesznek eleget (Chatman, 1991; O'Reilly Chatman, 1996).

Martin és Siehl (1983) egy olyan tipológiát fejlesztett ki a szervezeti szubkultúrákról, mely a vezetés által vallott kultúrához való viszony alapján három típust tartalmazott: támogató, semleges és ellenkultúrák. E típusokat azonosították a felsőoktatásban is. A Martin és Siehl (1983: p. 53.) által megnevezett semleges szubkultúra is létezhet azonban az oktatók között, ahol „párhuzamosan elfogadják az intézmény fó értékeit, ugyanakkor egy különálló, azzal nem ütközó értékcsoportot alkotnak." Habár az ellenkultúrák ritkaságszámba mennek a felsőoktatásban, ez nem jelenti azt, hogy nincs ellentét a domináns kultúrával szemben. Kuh és Whitt (1988: p. 50.) szerint „a megerósitó vagy semleges enklávék, mint például a kari/dékáni tanács, kihívást jelenthetnek a domináns kultúra számára." Úgy túnik, hogy a szubkultúrák változó mértékben kapcsolódnak a domináns szervezeti kultúrához.

A következókben az esetintézmény szempontjából releváns összeolvadás kulturális szempontjait vesszük górcsố alá a felsőoktatás vonatkozásában. 


\section{Az alkalmazott módszertan bemutatása}

A rendelkezésre álló eszközök számbavétele után a szervezeti kultúra mérésére a Szervezeti Kultúrát Értékelő Rendszert (OCAI) alkalmaztuk, amelynek alapja a versengő értékek modellje (CVF). Több szempont miatt esett a választás erre a modellre:

- elôször is, Cameron és Quinn (1999) modelljének eredeti megalkotása és bevezetése oktatási környezetben történt, és azóta is használják a szervezeti kultúra elemzésére számos felsôoktatási intézményben a világon (pl. Kleijnen et al., 2009; Ferreira - Hill, 2008),

- másodszor, a modell számos különböző kultúratípus egymás melletti létét teszi lehetôvé egyetlen szervezeten belül, ami ideálisnak tûnik a felsőoktatási intézmények fragmentált jellegét tekintve,

- harmadszor, segítette a választást, hogy ezt a modellt már használták Magyarországon, igaz, nem felsôoktatási intézmény esetében (Szabó - Csepregi, 2009; Gaál et al., 2010),

- végül pedig elmondható, hogy ez a módszertan azért került kialakításra, hogy megmutassa a jelen észlelését a szervezeten belüli preferenciák viszonylatában, további dimenziót adva ezáltal nemcsak az értékeknek, hanem magának a szervezet észlelésének is.

A CVF-et Quinn és Rohrbaugh (1983) fejlesztette ki azzal a céllal, hogy leírja vele a szervezetek hatékonyságát két bipoláris tengely mentén, ahol az egyik tengely a merevséget-rugalmasságot, a másik tengely pedig a külső-belsố fókuszt ábrázolja. A modellt az 1. ábra mutatja (Quinn, 1988: p. 48.).

\section{A versengó értékek modellje}

\begin{tabular}{|c|c|c|}
\hline Emberi kapcsolatok modell & rugalmasság & Nyitott rendszer modell \\
\hline $\begin{array}{l}\text { Eszköz: } \\
\text { kohézió, morál }\end{array}$ & & $\begin{array}{l}\text { Eszköz: } \\
\text { rugalmasság, cselekvöképesség }\end{array}$ \\
\hline $\begin{array}{l}\text { Eredmény: } \\
\text { az emberi eröforrás fejlödése }\end{array}$ & & $\begin{array}{l}\text { Eredmény: } \\
\text { növekedés, forrásszerzés }\end{array}$ \\
\hline befelé irányultság & & kifelé irányultság \\
\hline Belső folyamatok modell & & Racionális cél modell \\
\hline $\begin{array}{l}\text { Eszköz: } \\
\text { információ menedzselése, kommunikáció }\end{array}$ & & $\begin{array}{l}\text { Eszköz: } \\
\text { tervezés, célok megfogalmazása }\end{array}$ \\
\hline $\begin{array}{l}\text { Eredmény: } \\
\text { stabilitás, kontroll }\end{array}$ & merevség & $\begin{array}{l}\text { Eredmény: } \\
\text { termelékenység, gazdaságosság }\end{array}$ \\
\hline
\end{tabular}

Forrás: Quinn - Rohrbaugh (1983)
Az OCAI e modell alapján kialakított négy negyede a négy kulturális orientációt mutatja be. E modell esetében a kérdés nem az, hogy az adott kultúra melyik negyedbe sorolható be, sokkal inkább az, hogy melyik orientáció a leginkább domináns, ahogy az a 2. ábra grafikonján is látható.

2. ábra

Az OCAI négy kultúraorientációja és -dimenziója

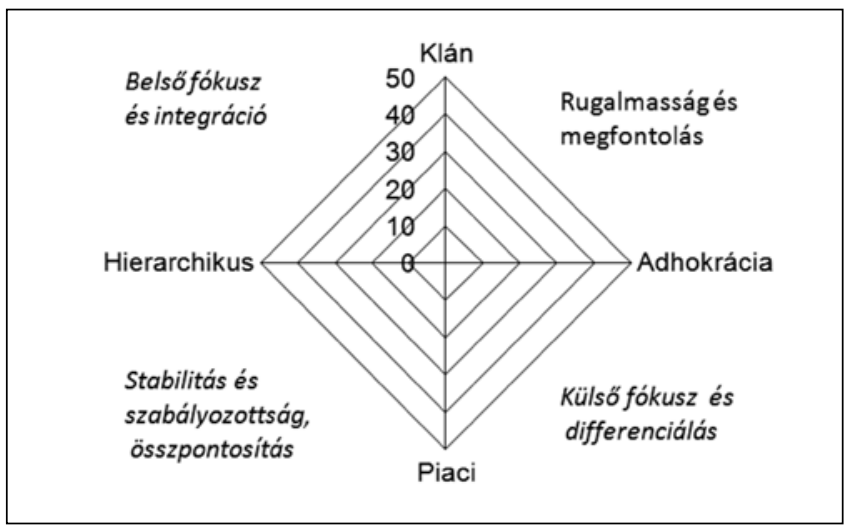

A fent említett négy típus a következő:

1. A klánkultúrát belsố kohézió, valamint közös értékek, együttmúködés és kollektivizmus jellemzi.

2. Az adhokráciakultúra ad hoc megközelítéseket alkalmaz a környezetból származó problémák megoldására, melyeket rugalmasan és nyitottan kezel.

3. A piaci kultúra határozott külsô fókusszal és piacorientációval rendelkezik, valamint az aktuális piaci részesedés megőrzésére/ 1. ábra bôvítésére törekszik.

4. A hierarchiakultúra belsó fókusszal bír, mely centralizált döntéshozatallal és a stabilitásra és ellenôrzésre való összpontosítással párosul.

Jelen feltáró vizsgálat szempontjából az elsődleges szempont a szervezeti kultúra kongruenciája.

A szervezeti kultúrát felmérô rendszer (OCAI) és a résztvevốk által a szervezeten belüli preferált értékekról megadott pontok felhasználásával elvégeztünk egy hierarchikus klaszteranalí- 
zist Ward-módszerrel, azzal a céllal, hogy azonosításra kerüljenek a potenciális szubkultúrák a szervezet gyakori értékei és észlelése szerint. Ezt a módszert már (Hofstede, 1998). Ily módon a résztvevốket klaszterekbe soroltuk a kultúradimenziók hasonlóságmértéke alapján, amit az SPSS statisztikai programmal elóállított dendogramból (fagráf) vezettünk le. Ahogy azt Hofstede (1998) is említi, annak a módszere ez, hogy a dendogram mely részét válasszuk ki a szervezeten belüli csoportosítás (klaszterezés) bizonyítására, vagyis hogy elérjük az optimális darabolást, hasonló a faktorelemzésnél használatos Scree-analízishez. A kultúra mérésére szolgáló változók dimenziószámának csökkentése érdekében faktoranalízist használtunk, majd az így elóállított faktorokból klasztereket hoztunk létre.

Az elemzés során korlátozó tényezô lehet, ha a dendogramon nagy léptékugrások vannak, ilyenkor célszerü az egyes egyedek (outlierek) elhagyása az elemzésből. Ha nincsenek nagy léptékugrások, akkor a homogenitás dominánsnak tekinthetô a szervezeten belül. korábban is használták a szubkultúrák azonosítására

\section{A minta}

2011-ben a szervezet minden szintjének összesen 959 alkalmazottja közül 369 fố töltötte ki a kérdőívet (38,5\%), melyből 3,5\% volt hiányos vagy érvénytelen az OCAI félreszámítása miatt, így a végsố minta $35 \%$ os (334 alkalmazott) volt.

\section{Az eredmények elemzése}

A dendogramból - melyet mérete és komplexitása miatt jelen tanulmány nem tartalmaz - egyértelmúen kiderült, hogy jelentős mértékú ugrások voltak attól a ponttól kezdve, ahol öt klaszter volt található - így ezek szubkultúráknak tekinthetốk. Két válaszadó kívülálló volt, ami két olyan klasztert eredményezett, ahol csak egy-egy válaszadó volt megtalálható. Ezeket kivontuk a tanulmányból, mivel egyéni alapon nem mutattak jelentős mértékú fragmentációt (tekintve, hogy csak két eset volt), és mivel a szubkultúrák meghatározásához szükséges, hogy interakció legyen a tagok között, így olyan szubkultúrák nem létezhetnek, melyek csak egy tagot számlálnak. A résztvevớk klasztereloszlását az 1 . táblázat ábrázolja.

1. táblázat A beazonosított szubkultúrákat ezt követôen vizsgálatuk kulturális orientáció/OCAI típusspecifikáció Számos kicsi, de jelentős számú kívülállót tartalmazó klaszter azonban létrehozza a saját klasztereit, ami magas szintú fragmentációt jelez a szervezeti kultúrán belül. Hofstede (1998) azt feltételezte, hogy ezek a klaszterek szubkultúrák a szervezeten belül. Feltételezve, hogy volt interakció a jelen esettanulmányban vizsgált mátrixszervezet válaszadói között - jóllehet változó mértékben -, ezek az értékcsoportok ugyancsak szubkultúráknak tekinthetók.

A második eszköz, amelyet a piaci orientáció felmérése érdekében alkalmaztunk ezen esettanulmány során a Market Orientation Inventory (Hemsley-Brown - Oplatka, 2010). Ezt a kérdőívet felsőoktatási környezetre alakították ki. Három dimenziót vesz figyelembe, melyek együttesen határozzák meg a piaci orientációt a felsőoktatási intézményekben:

- ügyfél-orientáció,

- versenytárs-orientáció és

- interfunkcionalitás-orientáció.

Az eszközt több országban is tesztelték, és megbízhatósága a Cronbach-skála szerint több mint 0,8 (Hemsley-Brown - Oplatka, 2010: p. 211.). szerint, mind észlelés, mind pedig értékek szempontjából azon hasonlóságok és különbségek feltárásával, melyek a szervezet és annak szubkultúrái között fennállnak. A 3. ábra grafikonja az egész szervezet eredményeit mutatja a saját magáról alkotott észlelés és a kívánt preferenciák vagy értékek viszonyában.

3. ábra

A kívánatos és valós értékek közötti eltérések a teljes szervezetnél

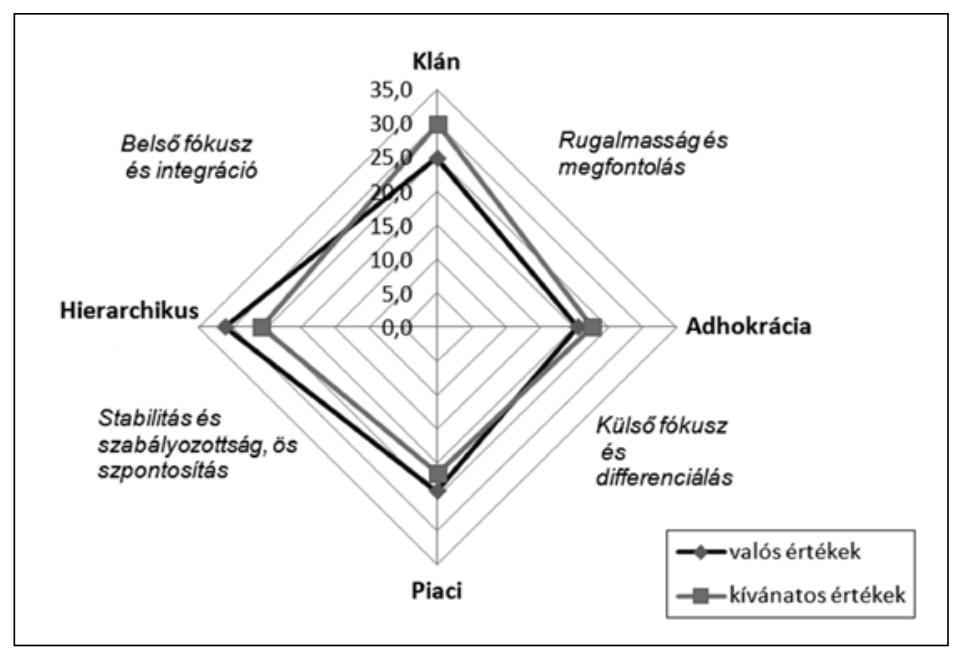


Ahogy az a 3. ábrán is látható, a szervezet a hierarchiatípust tekinti domináns kultúrának magára nézve, de a kinyilvánított értékek szerint a szervezet domináns kultúrája sokkal inkább a klánkultúra típusa.

A kívánatos és valós értékek összehasonlítása az 1. szubkultúra esetén

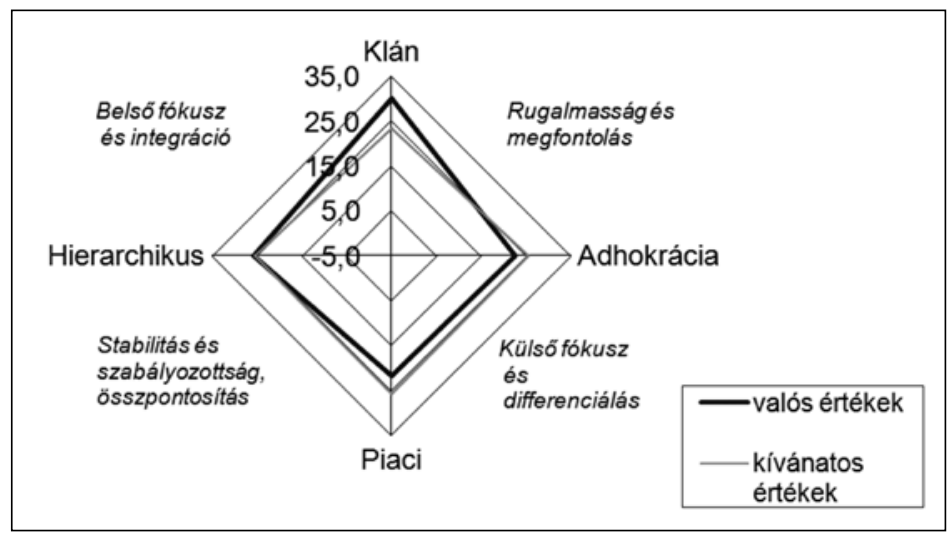

A kívánatos és valós értékek összehasonlítása a 2. szubkultúra esetén

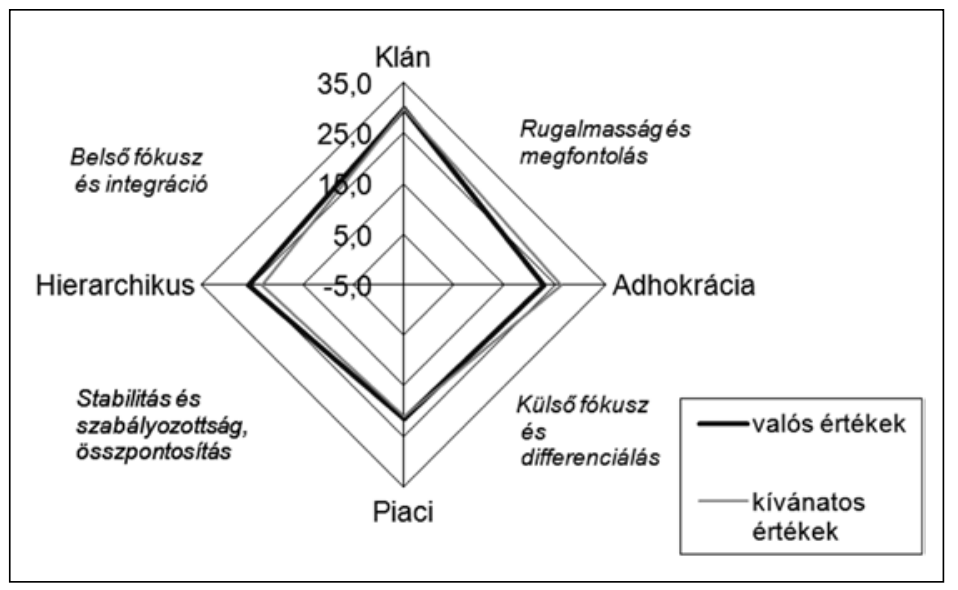

A kívánatos és valós értékek összehasonlítása a 3. szubkultúra esetén

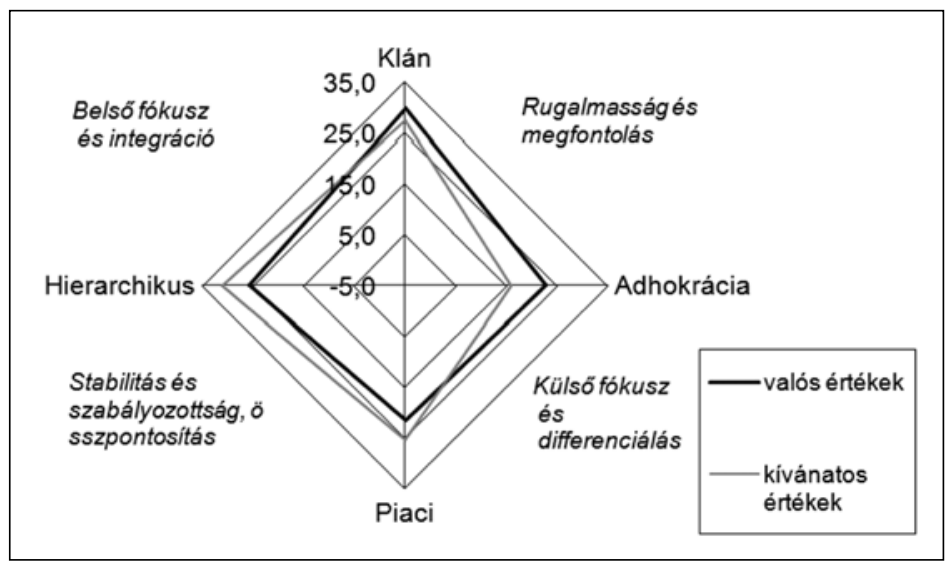

5. ábra

\section{1. szubkultúra - külsố fókuszos szubkultúra}

Ehhez a szubkultúrához a 332 válaszadóból 140 fő tartozott, mely nagy mérete miatt a minta domináns szubkultúrájának tû́nhet. A 4. ábrán ennek a domináns 4. ábra szubkultúrának a kifejezett értékeit és észlelései ábrázoltuk.

A szubkultúra sokkal inkább piacorientált és adhokratikus, mint a szervezet egésze, ami azt jelzi, hogy ez az adott szubkultúra nagyobb külső fókusszal és differenciálással rendelkezik. Nehéz megmondani, hogy ez a szubkultúra domináns-e vagy sem a teljes szervezetre nézve, mivel a 140 tag a szubkultúra egészét, vagy a teljesnek csak egy részét is reprezentálhatja. Így a tanulmányban (Martin - Siehl, 1983) korábban említett szubkulturális típusok szerint óvatosan előrebocsátható, hogy ez a szubkultúra egy semleges szubkultúra. Nagymértékben tartalmazza a domináns kultúrák értékeit különösebb eltérések nélkül, de egyben a saját, egyedi értékeit is, melyre nézve a szervezet egésze, mint hierarchikusan domináns típus, belsố fókusszal rendelkezik, ami - mivel ez a szubkultúra viszonylag egyedi külsố fókusszal bír - perifériálisnak tekinthető a domináns kultúra szempontjából.

\section{2. szubkultúra - fejlódó szubkultúra}

Ez a szubkultúra 84 válaszadót tartalmazott a 332-ból, ami által ez a szubkultúra a nagyobbak közé sorolható, jóllehet kb. feleakkora, mint az 1. szubkultúra. Ez a szubkultúra noha nem domináns, de a teljes szervezet tagjainak 1\%-a, a mintának pedig a 25,3\%-a tartozik ide.

Az 5. ábrán látható, hogy értékek szempontjából ez a szubkultúra a domináns szervezeti értékeket tükrözi. Ilyetén módon ez a szubkultúra fejlődő szubkultúrának tûnik, mely támogatja a szervezet értékeit és összhangot mutat a teljes szervezet fö értékeivel.

3. szubkultúra - stabilitás és kontroll szubkultúra

Ez a szubkultúra 34 válaszadót tartalmazott a 332 fős mintából.

A 6. ábrán látható, hogy a 3. szubkultúra adhokráciaorientációja igen gyenge, ami azt jelzi, hogy a preferencia a belsố fókuszon, valamint a stabilitáson és kontrollon van. A szervezetet kevésbé látja hierarchikusnak, mint amilyen valójában. Habár ez a szubkultúra nem tükrözi pontosan a szervezet egészének értékeit, mégis megerôsíti a domináns hierarchikus orientációt, ami révén ez a szubkultúra fejlődő szub- 
kultúra színében tetszeleg, jóllehet konfliktus jelentkezhet, amennyiben a szervezet nagyobb piaci vagy adhokráciaorientációra szeretne törekedni.

4. szubkultúra - erós hierarchikus szubkultúra

A szubkultúra 30 válaszadót tartalmaz a mintából, így ezzel ez a klaszteranalízis legkisebb szubkultúrája.

A kívánatos és valós értékek összehasonlítása a 4. szubkultúra esetén

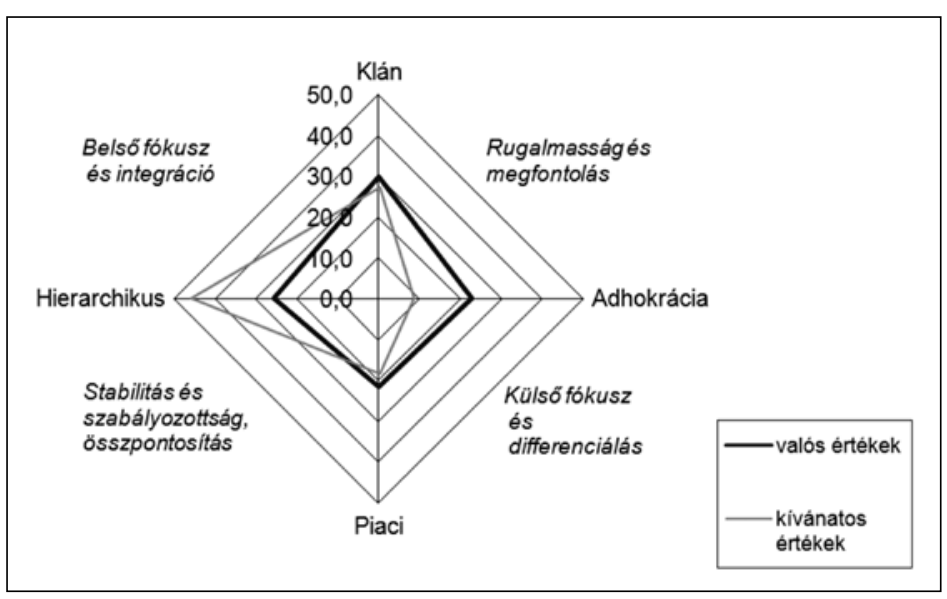

A kívánatos és valós értékek összehasonlítása az 5. szubkultúra esetén

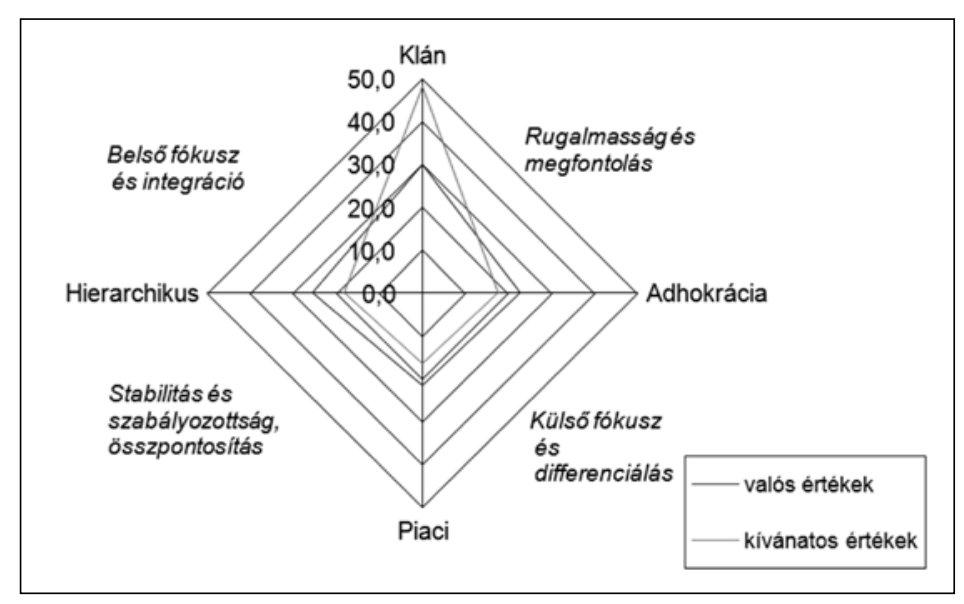

A 7. ábra adataiból az látszik, hogy ezt a szubkultúrát a domináns hierarchikus orientáció erôteljesen jellemzi. Valójában a skálát nagymértékben növelni kell ahhoz, hogy a hierarchiaorientáció magas pontszámát megfelelően láthassuk. A szubkultúra saját magát kevésbé piacorientáltnak érzékeli, mint amit az értékek ténylegesen mutatnak. A domináns hierarchiatípus igen

gyenge adhokráciatípus-értékekkel párosul. Mivel a szervezet hierarchiaorientációja domináns, ezért a szubkultúra erôs hierarchiaorientációja megerósíti ezt az irányú orientációt.

\section{5. szubkultúra - erốs klán szubkultúra}

Ez a szubkultúra 44 válaszadót tartalmaz a mintából. Noha ez a legkisebb klasztercsoport, mégis nagymértékben eltérô és erôs értékeket mutatott, ahogy az a 8 . ábrán is látható.

$\mathrm{Az}$ 5. szubkultúra egy igen domináns klánkultúra. Ez az orientáció szintén gyengítő hatással van a szubkultúra piacorientációjára. Habár a 4. szubkultúra szintén domináns kultúratípusú, de az egybeesett a szervezet domináns típusával. Az 5. szubkultúránál azonban úgy túnik, hogy vannak bizonyos közös értékek az átívelő szervezeti értékekkel, így például a belső fókusszal és az integrációval, mégis jelentős mértékú konfliktus van a szubkultúra rugalmassági és nyitottsági értékeivel, miközben a szervezet a stabilitást és a kontrollt értékeli.

\section{A szubkultúrák piacorientációi}

A szubkultúra-típusok felismerését követôen felmértük az egyes szubkultúrák, valamint a szervezet egészének piacorientációit. A felsőoktatási intézményeken elvégzett Market Orientation Inventory (MOI) kérdőív (HemsleyBrown - Oplatka, 2010) eredményeit a 2. táblázat tartalmazza.

Cameron és Quinn (1999) versengó értékek modelljét szem előtt tartva a piacorientált kultúrának külső fókusszal és a stabilitásra és kont-

Az öt szubkultúra piacorientációja

\begin{tabular}{|c|c|c|c|c|c|c|}
\hline & \multicolumn{5}{|c|}{ Szubkultúra } & \multirow{2}{*}{$\begin{array}{c}\text { A teljes minta } \\
\text { (Hierarchia) }\end{array}$} \\
\hline & $\begin{array}{c}1 \\
\text { Külsố fókusz } \\
\end{array}$ & \begin{tabular}{|c|}
2 \\
Fejlesztó hierarchia \\
\end{tabular} & $\begin{array}{c}3 \\
\text { Stabilitás/kontroll }\end{array}$ & $\begin{array}{c}4 \\
\text { Erós hierarchia } \\
\end{array}$ & $\begin{array}{c}5 \\
\text { Erốs klán }\end{array}$ & \\
\hline & Átlag & Átlag & Átlag & Átlag & Átlag & Átlag \\
\hline Hallgatóorientáció & 0,71 & 0,53 & 0,92 & 0,74 & 0,85 & 0,71 \\
\hline Versenyorientáció & 0,61 & 0,34 & 0,56 & 0,47 & 0,49 & 0,51 \\
\hline Kooperatívorientáció & 0,64 & 0,55 & 0,79 & 0,56 & 0,86 & 0,65 \\
\hline
\end{tabular}


rollra való törekvéssel egyaránt rendelkeznie kell. Ez bizonyos mértékig látszik is a szubkultúráknál abból, hogy a stabilitás/kontroll szubkultúra rendelkezik a legmagasabb átlaggal a hallgatóorientációnál, a második legmagasabb átlagot pedig a kooperatív orientáció hozza, továbbá a külsô fókusz rendelkezik a legmagasabb versenyorientációval. Cameron és Quinn (1999) modellje szerint a klántípus direkt kontrasztban áll a piacorientáció típussal, jóllehet a klántípus erôs kooperatív orientációt mutat. A versengố értékek modellje látszólag elhagyta a kooperatív orientációt, mivel része a piacorientációnak. Talán a modell oktatási környezetben történô eredeti tesztelésekor a piacorientáció ezen aspektusa viszonylag felderítetlen terület volt még.

A klán szubkultúra a versengó értékek modellje szerint belső fókusszal, és a második legerôsebb hallgatóorientációval rendelkezik. Ez látszólag azt jelzi, hogy a hallgatóorientáció a belső fókusz részét képezi, ami érthetônek tûnik, mivel a hallgatók oktatása és fejlesztése olyan napi szintü folyamat, mely a szervezeten belül zajlik. Ugyanakkor a felmérésből kiderül, hogy a válaszadók 86\%-a ügyfélnek tekintette a hallgatókat. Ily módon az ügyfelek külső fókuszként jelennek meg, nem pedig belsô fókuszként. Itt érdemes majd értelmezni az ügyfél és a stakeholderek fogalmát és különbségeit, ami láthatóan nem tisztázott a szervezet esetében.

\section{Következtetések}

Az esettanulmány eredményei számos olyan kérdést felvetettek, melyek további kutatást igényelnek, és rámutattak néhány olyan fontos szempontra, amit célszerü figyelembe venni a felsőoktatási intézmények kultúrájának kutatásakor.

Jelen tanulmány amellett, hogy feltárta és beazonosította a szubkultúrákat egy adott felsőoktatási intézményben, aláhúzta a szervezetfejlesztés fő problémáit a nagy szervezetek szervezeti szubkultúráinak összeegyeztetésével kapcsolatban, ahogy azt Hopkins, Hopkins és Mallette (2005) is jelezte. Az intézménynek figyelembe kell vennie, hogy a sikerhez vezetố út a tagoktól konformitást igénylő homogén kultúrán át, vagy egy „,szubkulturális megközelitésen" át vezet, ami olyan szervezeti funkciók igénybevételét is jelenti, mint a humán eróforrások menedzsmentje és a marketing, és a szervezeten belül nagyon eltéró piacorientáltság(ok)at is jelenthet, ahogy azt ez az eset is mutatja (Palthe - Kossek, 2002).

Ezen túlmenôen az a tény, hogy az összeolvadás nem eredményezett egyetlen integrált kultúrát az eltelt 14 év alatt, arra enged következtetni, hogy bizonyos mértékben elkerülhetetlen a szubkultúrák túlélése a felsőoktatási intézményekben - a nagymértékú átalakítá- sok (pl. összeolvadás vagy mátrix szervezeti struktúra bevezetése) ellenére is. Ami az alkalmazkodást illeti, az összeolvadáson átesett szervezetek esetében (Heidrich - Chandler, 2011), úgy túnik, hogy az akkulturáció végbement a szubkultúráknál a fizikai határok mentén, habár ezen esettanulmány kapcsán is szükség lehet egy longitudinális vizsgálatra az akkulturációról.

Az eredmények azt is jelzik, hogy a piacorientáció egyik aspektusa a felsőoktatási intézményeknél (számos egyéb szervezettôl eltérốn) a külsố és belsô fókusz. A klán szubkultúratípus nagyobb belső fókusszal rendelkezik, mégis magas a hallgatóorientációja - valójában a második legmagasabb az öt szubkultúratípus közül. Ha azonban a hallgató az ügyfél, és az ügyfélfókusz külső fókuszként jelenik meg, akkor felmerül a kérdés, hogy a hallgatón mint ügyfélen lévő fókusz valóban külső fókusz-e a felsőoktatási intézményeknél, vagy inkább belsố fókuszként szükséges figyelembe venni, esetleg másféle értelmezési keret szükséges. A hallgatói kultúrát közvetlenül befolyásolja az oktatói gárda, akik sokkal több idôt töltenek a hallgatókkal, mint a kollégákkal. A külső és belső fókusz számos piacorientált modellnél újragondolást igényelhet, amenynyiben azokat a felsőoktatási szervezeteken vizsgáljuk.

Jelen empirikus vizsgálat arra a hierarchikus klaszteranalízisre épít, mely a szubkultúrák azonosítására szolgál, és amely egy lehetséges módszertant mutat be a szervezetek és szubkultúráik közti közvetlen öszszehasonlítás elkészítéséhez, a szervezeti értékekkel és észlelésekkel való kapcsolódásuk felderítésével és szembeállításával.

\section{Lábjegyzet}

' A szerző́k köszönetet mondanak dr. Kása Richárdnak (BGF Kutatóközpont, PSZK) az empirikus kutatásban nyújtott segítségéért.

\section{Felhasznált irodalom}

Barakonyi K. (2010): A felsőoktatás versenyképességéról. Vezetéstudomány, Vol. 41. december: 4-19. o.

Becher, T. (1987): The disciplinary shaping of the profession. in: B. R. Clark (ed.): The academic profession. Berkeley: University of California Press

Berács J. (2001): Rendszerváltás előtt a magyar felsőoktatás. Vezetéstudomány, 3.: 41-53. o.

Bowen, H. - Schuster, J. (1986): American professors: A national resource imperiled. New York: Oxford University Press

Burke, M. - MacKenzie, M. (2002): Working effectively within a changing organisational environment. Student Support Services. Brisbane, Australia: University of Queensland

Cameron, K.S. - Quinn, R.E. (1999): Diagnosing and changing organizational culture. Reading, M.A.: Addison Wesley Longman 
Chaffee, E.E. - W.G. Tierney (1988): Collegiate Culture and Leadership Strategies. New York, NY: Macmillan

Chandler, N. (2011): A New Era Market-Orientation and the Diverse Organisational Culture of Higher Education Institutions (HEIs). Retrieved from http://www. thefreelibrary.com/

Chatman, J. (1991): Matching people and organizations: Selection and socialization in public accounting firms. Administrative Science Quarterly, 36: 459-484. o.

Day, G.S. (1999): The Market Driven Organization: Understanding, Attracting, and Keeping Valuable Customers. New York: The Free Press

Ferreira, A. - Hill, M. (2008): Organizational Cultures in Public and private Portuguese Universities: a case study. The International Journal of Higher Education and Educational Planning, Vol. 55: 637-650. o.

Gaál Z. - Szabó L. - Obermayer-Kovács N. - Kovács Z. - Csepregi A. (2010): Clan, adhocracy, market or hierarchy? Which is the best for knowledge sharing in Hungary? ECIC. Retrieved from http://www.academicconferences.org/ecic/ecic2010 /ecic10-proceedings.htm (accessed 7 January 2012)

Handy, C. (1993): Understanding organisations. London: Penguin

Heidrich, B. - Chandler, N. (2011): The effect of marketoriented subcultures on post-merger higher education institutions. US-China Education Review, Volume 1, No. 5, October 2011.

Hemsley-Brown J. - Oplatka I. (2010): Market orientation in universities: a comparative study of two national higher education systems. International Journal of Educational Management, Vol. 24. No. 3: 204-220. o.

Hofstede, G. (1980): Culture's consequences: International differences in work-related values. Newbury Park, CA: Sage

Hofstede, G. - Neuijen, B. - Daval Ohayv, D. - Sanders, G. (1990): Measuring organizational cultures: A qualitative and quantitative study across twenty cases. Administrative Science Quarterly, 35: 286-316. o.

Hofstede, G. (1991): Cultures and Organizations. Berkshire: McGraw-Hill Europe

Hofstede, G. (1998): Identifying organizational subcultures: An empirical approach. Journal of Management Studies, 35: 1-12. o.

Hopkins, W.E. - Hopkins, S.A. - Mallette, P. (2005): Aligning Organizational Subcultures for Competitive Advantage. New York: Basic Books

Hurley, R.F. - Hult, G.T.M. (1998): Innovation, Market Orientation and Organizational Learning: An Integration and Emprical Examination. Journal of Marketing, 1998, Vol. 62: 42-54. o.

Kasper, H. (2005): The culture of market oriented organisations. Maastricht University. FdEWB (Working Paper)

Kleijnen, J. - Dolmans, D. - Muijtjens, A. - Willems, J. Van Hout, H., (2009): Organisational Values in Higher Education: Perceptions and Preferences of Staff. Quality in Higher Education, 15, 3: 233-249. o.

Kohli, A.K. - Jaworski, B.J. (1990): Market orientation: The construct, research propositions and managerial implications. Journal of Marketing, Vol. 54: 1-18. o.
Kuh, G. - Whitt, E. (1988): The invisible tapestry. Culture in American Colleges and Universities. ASHE-ERIC Higher Education, Report No.1.

Martin, J. (1992): Cultures in organizations: Three perspectives. New York: Oxford University Press

Martin, J. - Siehl, C. (1983): Organizational culture and counterculture: An uneasy symbiosis. Organizational Dynamics, 122: 52-65. o.

Meadmore, D. (1998): Changing the Culture: the governance of the Australian pre- millennium university. International Studies in Sociology of Education 8 (1)

Nagy G.-Berács J. (2013): Az exportpiac-orientáció elózményei és annak exportteljesítményre gyakorolt hatása a magyar felsőoktatási intézményekben. Vezetéstud., 44 (2): 2-19. o.

Narver, J.C. - Slater, S.F. (1990): The effect of a market orientation on business profitability. Journal of Marketing, October: 69-73. o.

Narver, J.C. - Slater, S.F. (1994): Market Orientation, Customer Value, and Superior Performance. Business Horizons, 37: 22-28. o.

Oplatka, I. - Hemsley-Brown, J. (2007): The incorporation of market orientation in the school culture: an essential aspect of school marketing, International Journal of Educational Management, Vol. 21, No. 4: 292-305. o.

O'Reilly, C. - Chatman, J. (1996): Culture as social control: Corporations, cults and commitment. in: B. Staw - L. Cummings (eds.): Research in organizational behavior. Vol. 18., Greenwich CT: JAI Press: 157-200. o.

Palthe, J. - Kossek, E. (2002): Subcultures and employment modes: translating HR strategy into practice, Journal of Organizational Change Management, Vol. 16, No. 3: 287-308. o.

Quinn, R.E. - Rohrbaugh, J. (1983): A spatial model of effectiveness criteria: Towards a competing values approach to organizational analysis. Management Science, 29: 363-377. o.

Quinn, R.E. (1988): Beyond rational management: Mastering the paradoxes and competing demands of high performance. San Francisco: Jossey-Bass

Schein, E. (1988): Organizational socialization and the profession of management. Sloan Management Review, 30: 53-65. o.

Schein, E. (1985): Organizational culture and leadership. San Francisco: Jossey-Bass

Slater, S.F. (2001): Market orientation at the beginning of a new millennium. Managing Service Quality, Vol. 11, Iss. 4: 230-233. o.

Szabó L. - Csepregi A. (2009): A gazdasági válság hatása a szervezeti kultúra alakulására - jó irányba megyünk? Harvard Business Review, 11. évf. 11 sz.: 29-35. o.

Temesi J. (2012): Nemzetközi felsôoktatás-finanszírozási trendek: tanulságok és javaslatok 2012 elején. Nemzetközi tendenciák és a hazai helyzet. Bp.: Aula: 320-338. o.

Tierney, W.G. (1988): Organizational culture in higher education: Defining the essentials. Journal of Higher Education, 59(1): 2-21. o.

Trice, H. - Beyer, J.M. (1993): The culture of work organizations. Englewood Cliffs, N.J: Prentice-Hall

Weber P.S. - Weber J.E. (2001): Changes in employee perceptions during organizational change. Leadership and Organization Development Journal, 22(6): 291-300. o. 